\title{
Inclusion of Notary Self-Protection Clause in Authentic Deed Reviewed from Notary Department Law and Notary Code of Ethics
}

\author{
Muhammad Guntur Gunawan ${ }^{1} \quad$ Salim $^{2} \quad$ Aris Munandar $^{2}$ \\ 1.Notary Masters Study Program Students, Faculty of Law, Mataram University, Indonesia \\ 2.Lecturer of Faculty of Law, Mataram University, Indonesia
}

\begin{abstract}
A notary is a public official who has a very important role and position in the life of the nation and state. Notaries are authorized to make authentic deeds and have other authorities as referred to Notary Position Law or based on other laws. Authentic deeds made by a notary in practice are often disputed by one party or another because it is considered detrimental to their interests. The existence of a problem between the parties in the notary deed then involves the notary in the examination and settlement process. This makes the Notary dragged by the lawsuit filed by the litigants in the deed. Therefore, Notary public wants to strengthen their own protection by adding /including a self-protection clause in their deed. This study aims to analyze the inclusion of notary self-protection clauses in authentic deed based on the law of notary positions and notary code of ethics. This research is normative and empirical, with data collection tools in the form of document studies and sample collection through interview methods. Types and sources of data consisting of primary data and secondary data. Processing of data by editing and analyzing data by means of quantitative and qualitative analysis. This study uses several approach methods such as: the statute approach, the conceptual approach, the case approach, and the sociological approach. The researcher wants to conduct research at the Notary's office located in the area of Mataram City and West Lombok Regency, West Nusa Tenggara. The results showed that the inclusion of a notary self-protection clause in a notary deed has no legal basis. It can be said that because in Article 38 of the Law on Notary Positions which outlines the systematics of each notary deed, there is no provision that regulates the notary self-protection clause. This is also in accordance with the provisions of Article 53 of the Law on Notary Positions that the notary deed is not allowed to regulate provisions that give rights and/or benefits to the notary himself. Therefore, the inclusion of a notary self-protection clause in the notary deed is considered inappropriate and deviates from existing rules.
\end{abstract}

Keywords: Notary, authentic deed, notary code of ethics, self-protection clause.

DOI: $10.7176 / \mathrm{JLPG} / 112-03$

Publication date:August $31^{\text {st }} 2021$

\section{INTRODUCTION}

Notaries have a very important position and role in the life of the nation and state, because they have the authority that has been determined in the legislation. ${ }^{1}$ Article 1 number 1 of Law No. 2 of 2014 concerning Amendments to Law No. 30 of 2004 concerning Notarial Positions, notaries are public officials authorized to make authentic deed and have other authority as referred to in this Notary Department Law or based on other Laws.

The authority of a notary has been regulated in Law Number 2 of 2014 amendments to Law Number 30 of 2004 concerning the Position of a Notary, in Article 15 paragraph (1) concerning the authority of a notary, namely a notary has the authority to make authentic deeds regarding all acts, agreements, and required by laws and/or desired by the interested parties to be stated in an authentic deed, guaranteeing the certainty of the date of making the deed, keeping the deed, providing grosse, copies and quotations of the deed.

The perfection of a notarial deed as evidence cannot be doubted. In making an authentic deed, of course, it must meet the provisions or conditions that have been determined by law.

To be said to be an authentic deed, a deed must meet material and formal requirements.

Material requirements such as; ${ }^{2}$

1. Contains information on the agreement of the parties,

2. Fill in the statement of legal action,

3. The deed is intentionally made as written evidence.

While the formal requirements such as $;^{3}$

1. Must be made before the competent authority,

\footnotetext{
${ }^{1}$ Salim HS, Peraturan Jabatan Notaris, (Jakarta: Sinar Grafika,2018) hlm.26

${ }^{2}$ Salim HS, Teknik Pembuatan Akta Satu (Konsep Teoretis, Kewenangan Notaris, Bentuk Dan Minuta Akta) (Jakarta : Rajawali Pers, 2016), hlm, 28

${ }^{3} \mathrm{Ibid}$.hlm 29.
} 
2. Attended by the parties, both parties are known or introduced to officials,

3. Attended by two witnesses,

4. Mention the identity of the notary (official), the confronters and witnesses.

5. Mention the place of day, month and year of making the deed.

6. The notary reads the deed in front of the public.

7. Signed by all parties.

8. Confirmation of reading, translation and signing at the closing of the deed

Based of all authorities given to notaries, Notaries also cannot be separated from the responsibility for the given authority. A Notary in his position as a public official has responsibilities related to the deed he made, this is in accordance with Article 65 of the Notary Office Act, that:

"Notary Public, Substitute Notary, and Notary Provisional Officer are responsible for any deed made even though the Notary Protocol has been submitted or transferred to the notary protocol."1

From article 65 of the Law on the Position of a Notary, it can be concluded that the responsibility of a notary will still exist even though he has stopped or retired from his position, the responsibility of a notary will remain attached and even until a notary dies.

An authentic deed made by a notary in practice is not infrequently disputed by one party or by another party because it is considered detrimental to his interests, whether it is by denying the contents of the deed, signature or the presence of the party before a notary, even allegations in the authentic deed are found false information.

The existence of an issue between the parties in the notary deed then involves the notary in the examination and settlement process. Notaries tend to be dragged along by the lawsuit filed by the parties in the deed. The notary being dragged into the examination process was not due to personal malice, but was dragged by the litigants.

Lack of understanding among legal practitioners about the role of notary public which is basically only as a neutral or impartial official, causes notaries are often suspected of involvement in violations or crimes committed by the parties in the deed when it should be notary regardless of such allegations. This issue caused concerns among notaries, concerns both in terms of the length of the examination process, the continuity of notary reputation, and other concerns.

In relation to this, the notary wants to strengthen his own protection, which actually by following the provisions set by the law of notary position has received sufficient protection. However, there are some notaries who add protection for themselves by adding / including a self-protection clause in the deed they make in order to get safer protection and of course for prudential efforts and increase notary confidence.

In an effort to minimize the alleged involvement of a Notary in the violation or crime of the parties, the Notary then adds provisions and rules for self-protection in the deed aimed at protecting the Notary. The addition of these provisions and rules is intended so that the notary is not involved in the material examination of the problems that occur between the parties in the deed.

The Self-Protection Clause is a clause that states that if in the future there is information that is not in accordance with the deed, there is a dispute or there are things / information that one day proved incorrect from the confronters themselves, then it will not involve notary public.

The inclusion of a notary self-protection clause in this notarial deed is ambiguous and has no clear legal force, because the contents in a deed are an agreement of the parties made before a notary in accordance with what is contained in article 38 paragraph 3 letter (C) Law on the position of a notary (UUJN) which reads as follows:

"The contents of the deed which is the will and desire of the interested party"

And based on article 1338 of the Civil Code concerning the consequences of an agreement, it reads as follows :

"All legally made agreements apply as law to those who make them"

The agreement applies to those who make it as stated in the article above, in the event that there is a promise for a third party and then he accepts the promise or right, it means he is bound by the agreement. It is the same with the inclusion of this self-protection clause in the deed which determines the promise or right of protection for the notary as a third party. That is, there is a conflict of interest because the self-protection clause for the notary is the right of the notary while the notary is not part of the parties and the notary is not allowed to have or get the rights in the deed he made.

Article 53 of the Law on Notary Positions (UUJN) regulates this matter which reads as follows:

"The Notary Deed may not contain stipulations or provisions that give rights and/or benefits to the:

a. Notary, wife or husband of Notary;

b. witness, wife or husband of the witness; or

\footnotetext{
${ }^{1}$ Pasal 65 Undang-Undang Jabatan Notaris No. 2 Tahun 2014 Perubahan Atas Undang-Undang Jabatan Notaris No 30 Tahun 2004 tentang Jabatan Notaris .
} 
c. a person who has a family relationship with a Notary or witness, whether blood relationship in a straight line up or down without any limitation on degree or marital relationship up to the third degree."

Judging from these articles, the notary is authorized to make a deed based on the wishes of the parties, but the notary is not included in these parties, which means that the notary is not authorized to state what he wants and the notary is prohibited from including stipulations or provisions that can provide benefits or a right. for a notary, so it is questionable what is the legal basis for the inclusion of a notary self-protection clause that is included in the deed, and what is the background for a notary to use this self-protection clause.

In connection with these matters, the author is interested in analyzing the notary self-protection clause in the form of a thesis with the title "Inclusion of the Notary Self-Protection Clause in an Authentic Deed Based on the Law on Notary Positions and the Notary Code of Ethics.".

\section{RESEARCH METHOD}

This type of legal research is normative and empirical. The approach used in this research is the statute approach, the conceptual approach, the case approach, and the sociological approach. The types and sources of data used in this study are primary data and secondary data. Primary data is data obtained directly from sources in the field through research. ${ }^{1}$ Secondary data is data obtained through literature study and document study. Secondary data is data needed to complement and support primary data. Primary data collection techniques and tools were obtained by collecting samples by means of interviews. Secondary data collection techniques and tools are obtained by reading and studying in depth several literature books related to the making of a notarial deed. Data processing By editing, namely by re-examining the records, files, information collected by data seekers which are expected to improve the quality of the reliability of the data to be analyzed. Data analysis can be classified into two types, namely quantitative and qualitative analysis.

\section{The Result}

\section{Legal Basis for Inclusion of a Self-Protection Clause}

\section{A. Notary Authority}

The authority of a Notary is contained in Article 15 paragraph 1 of the Law on Notary Positions which states that a Notary has the authority to make an authentic deed regarding all acts, agreements, and stipulations required by laws and regulations and/or desired by the interested parties to be stated in an authentic deed, guaranteeing the certainty of the date of making the deed, keeping the deed, providing grosse, copies and quotations of the deed, all of this as long as the making of the deed is not assigned or excluded to other officials or other people stipulated by law.

In Article 15 paragraphs 1,2 and 3 of the Law on Notary Positions, Notaries are also authorized in matters, namely:

1. Notaries are authorized to make authentic deeds regarding all actions, agreements and provisions required by legislation and or desired by those with an interest to be stated in an authentic deed, guarantee the certainty of the date of making the deed, save the deed, provide Grosse, copies and quotations of the deed, all of them that as long as the making of the deeds is not assigned or excluded to other officials or other people stipulated by law..

2. Notary is also authorized:

a. Validate the signature and determine the certainty of the date of the letter under the hand by registering it in a specific book;

b. Book a letter under the hand by registering in a special book;

c. Make a copy of the original underhand letter in the form of a copy containing the description as written and described in the letter in question;

d. Validate the compatibility of the photocopy with the original letter;

e. Provide legal counseling in connection with the making of the Act;

f. Make a deed related to land; or

g. Make a deed of minutes of auction.

3. In addition to the authority stipulated in paragraphs 1 and paragraph 2, notaries have other authority stipulated in the Laws and Regulations.

Based on Article 15 paragraph (3) of UUJN, a Notary public has other authority stipulated in the legislation. If a Notary Public acts outside the prescribed authority, then the Notarial deed is not legally binding or cannot be carried out. Parties who feel aggrieved by the notary's actions can be sued civilly to the district court.

'Abdulkadir Muhammad, Op Cit, hlm. 134 


\section{B. The Parties of the Notary Deed}

The parties are those who want an agreement or stipulation to be written authentically in a notarial deed. That is, the parties must be parties with an interest in the matters to be stated in the notarial deed. That is, in the context of making a deed, the parties are only those who have an interest in the contents of the deed. However, in a different context, in its explanation, the Law on Notary Positions also states that the parties with an interest in a notary deed are the parties or their proxies. only those who have an interest in/to the deed are obliged to become parties. In this case, the parties are the parties who carry out legal actions.

When the parties come to the Notary so that their actions or actions are formulated into an authentic deed in accordance with the authority of the Notary, and then the Notary makes a deed at the request or desire of the parties, then in this case it provides a basis for the Notary and the parties there has been a legal relationship between the two. Notaries themselves must provide the best service to the parties or the community, but the Notary can refuse to provide services to the parties or the community for certain reasons, this is regulated in Article 16 paragraph (1) letter e of the UUJN. Legal subjects who come to the Notary are based on their own needs and desires, the Notary cannot do a job or make a deed without a request from the parties, thus according to the Notary in the form of representing other people without power (zaakwaarneming) it is impossible based on Article 1354 Civil Code. ${ }^{1}$

The legal relationship that occurs between the Notary and the parties cannot be constructed, ascertained or determined, from the beginning into the form of existence or a breach of contract or an act against the law (onrechtmatigedaad) or approval to do certain jobs or represent other people without power (zaakwaarneming) which can be used as a basis for suing a Notary in the form of reimbursement of costs, compensation or construction interest as cannot be applied directly to a Notary because there are no conditions that are met such as:

1. There is no written agreement or power of attorney or to enter into certain agreements;

2. No rights of the parties or the confronters are violated by the Notary;

3. The notary has no reason to receive an order to do a job;

4. There is no voluntary notary to make a deed, without any request from the parties.

Based on this explanation, it can be concluded that when a notary makes a deed, basically the notary only makes a deed at the request of the parties, here the notary must translate articles, sentences, verses, so that they are in harmony and obtain legal force. In carrying out their duties and positions, the Notary must adhere to the UUJN and the Notary Code of Ethics so that when carrying out his duties the Notary is always procedural as it should be contained in the Notary Position Act and the Code of Ethics so that the deed made by the Notary can provide legal certainty to the parties who made the deed.

\section{Notary Arrangements In Running His Position. \\ 1.Law on Notary Position}

Along with the times, several provisions in Law Number 30 of 2004 concerning the Position of a Notary are no longer in accordance with legal developments and the needs of the community so that changes need to be made. In addition, notaries as public officials who carry out the profession in providing legal services to the public, need to get protection and guarantees in order to achieve legal certainty. Therefore, on January 15, 2014, Law Number 2 of 2014 was passed concerning amendments to Law Number 30 of 2004 concerning the Position of Notary.

In the notary field, concrete efforts as a manifestation of the principles of certainty, order, and legal protection are applied in the form of making a deed that has perfect evidentiary power because it is made by an authorized official, namely a notary. Notaries and their legal products in the form of authentic deeds can be interpreted as state efforts to create legal certainty for community members. Considering that in the area of civil law, the state places a notary as a public official who is authorized in terms of making an authentic deed, for the sake of proof or evidence. ${ }^{2}$

Notary Position Act Article 16 paragraph (1) is a law that regulates the obligations of Notaries in carrying out their positions. The prohibition for Notaries is regulated in Article 17 paragraph (1) of the Law on Notary Positions which contains actions that are prohibited to be carried out by a Notary. For notaries who violate the provisions, they will be subject to sanctions as stipulated in Article 17 paragraph (2) in the form of:
a. A written warning;
b. Temporary termination;
c. Dismissal with respect; or
d. Disrespectful dismissal.

\footnotetext{
${ }^{1}$ Habib Adjie, 2008, Hukum Notaris Indonesia (Tafsir Tematik Terhadap UU No. 30 Tahun 2004 Tentang Jabatan Notaris), PT. Refika Aditama, Bandung, hlm 18.

${ }^{2}$ Munir Fuady, Hukum Bisnis Dalam Teori Dan Praktek, (Bandung: Citra Aditya Bakti, 2002) hal. 77.
} 


\section{Notary Code of Ethics}

The notary code of ethics is the entire moral code that guides in carrying out the position of a notary. The scope of the notary code of ethics applies to all members of the Association as well as other people who hold and carry out the position of a notary, both in the implementation of the position and in daily life. Notaries who carry out the profession must comply with an internal regulation that applies in a certain professional organization. The notary code of ethics also plays an important role as a means of social control. ${ }^{1}$

The provisions in Article 1 point 2 of the Notary Code of Ethics, state that the Code of Ethics is the entire moral code determined by the Indonesian Notary Association, hereinafter referred to as the "Association" based on the Decree of the Association's Congress and/or determined by and regulated in the laws and regulations that regulates about that and applies to and must be obeyed by each and all members of the association and all people who carry out their duties as a Notary, including Temporary Notary Officials, Substitute Notaries.

The Notary's obligations are regulated in the Notary Code of Ethics, namely in Article 3. The Notary Code of Ethics also regulates the prohibition for Notaries contained in Article 4. In addition to the obligations and prohibitions for Notaries, there are exceptions for Notaries which are regulated in Article 5 notary code of ethics. The following are not included as violations, namely:

a. Giving congratulations, condolences by using greeting cards, letters, bouquets or other media with no notary, but only the names;

b. Loading of notary names and addresses in telephone, fax and telex number manuals, officially published by PT. Telkom and/or other agencies and/or institutions;

c. Installing 1 (one) sign with a size not exceeding $20 \mathrm{~cm} \times 50 \mathrm{~cm}$, white base, black letters, without stating the name of notary public and installed within a maximum radius of $100 \mathrm{~m}$ from the Notary office;

d. Introducing without promoting as a Notary Public.

\section{Inclusion of the Self-Protection Clause in the Notary Deed}

\section{a.Anatomy of a Notary Deed}

Article 1868 of the Civil Code is a source for the authenticity of a notary deed, it is also the basis for the legality of the existence of a notary deed, with the following conditions:

a. The deed must be made by or before a public official;

b. bThe deed must be made in the form determined by law;

c. Public officials by or before whom the deed was made, must have the authority to make the deed.

An agreement contains several fundamental principles that form an agreement. The fundamental principles in the formation of an agreement are as follows: ${ }^{2}$

a. The principle of freedom of contract

b. The principle of consensualism

c. The Principle of Legal Certainty (Pacta Sunt Servanda)

d. The principle of good faith

An agreement must fulfill the principles mentioned above. Apart from that, the making of a deed also has a certain structure/framework that must be followed. The framework or arrangement of a deed can be explained into several divisions as follows:

a. Opening of the Deed, which includes:

1) The title of the deed is the name of the agreement or statement/stipulation which is the content of the deed.

2) Deed number is the serial number of the deed made in a certain month.

3) The day and date of the deed is the inclusion of the day, date, month and year the deed was made.

b. Comparison, which includes:

Information on the legal subjects that make the agreement, namely the identity of the parties and the position of the parties. A person facing a notary for the making of a deed may act:

1) For himself;

2) For and on behalf of another person through power of attorney;

3) Act in position;

\footnotetext{
${ }^{1}$ Abdulkadir Muhammad, Etika Profesi Hukum, (Bandung: Citra Aditya Bakti, 2006), hal.56.

${ }^{2}$ Muhammad Syaifuddin, Hukum Kontrak, (Bandung: Mandar Maju, 2012), hal. 115.
} 
4) Acting in office.

c. Premise

It can also be called the background of an agreement which explains the intentions and objectives of the parties, contains the reasons or basis for consideration of the existence of the agreement.

d. Contents of the Deed, which includes:

Articles and clauses which are the result of an agreement between the parties that contain the will of the parties concerned, include all matters and points deemed necessary, explain the rights and obligations of the parties.

e. Closing of Deed, which includes:

1) The place where the deed was made, it is important to include it to determine whether the deed was indeed made in the working area of the notary concerned;

2) The identity of the witnesses, including the names, occupations, places of residence of the witnesses;

3) It is also mentioned that the deed has been read to the confronters and witnesses;

4) Signatures of the confronters, witnesses and the Notary.

The framework of a Notary deed is then regulated in the applicable regulations, namely Article 38 of the Law on Notary Positions which is divided into 3 (three) parts. To meet the authentic requirements, a Notary deed must have the anatomy of a deed in accordance with what is stipulated in Article 38 of the Notary Position Act, namely:

a. The beginning of the deed or the head of the deed, contains:

1) Title of deed;

2) Deed number;

3) Hour, day, date, month, and year; and

4) Full name and domicile of Notary.

b. Deed body, contains:

1) Full name, place and date of birth, nationality, occupation, position, position, residence of the confronters and/or persons they represent;

2) Information on the position of the confronters action;

3) The contents of the deed which is the will and desire of the interested party; and

4) The full name, place and date of birth, as well as the occupation, position, position, and residence of each identifying witness.

c. End or closing of the deed, contains:

1)A description of the reading of the deed as referred to in Article 16 paragraph (1) letter $\mathrm{m}$ or Article 16 paragraph (7);

2)Description of the signing and place of signing or translation of the deed, if any;

3)Full name, place and date of birth, occupation, position, position, and residence of each witness to the deed; and

4)A description of the absence of changes that have occurred in the making of the deed or a description of any changes that may be in the form of additions, deletions, or replacements as well as the amount of the changes.

From the descriptions above, the framework of a deed has been clearly regulated in the applicable regulations and is divided into 3 (three) parts. Regarding the title of this thesis research which discusses clauses, it can be seen that according to Article 38 of the Law on Notary Positions, clauses are the contents of the deed which is part of the deed body. The contents of the deed are the will/desire of the parties concerned which are poured into articles and clauses.

\section{b. Responsibility for the Contents of the Deed}

The contents of the deed are part of the body of the deed which contains things in the form of statements or agreements made by the parties requesting the deed to be made. The contents of a notarial deed can be divided into 2 (two) types, namely: ${ }^{1}$

a. Things that are desired and requested by interested parties to be stated in a Notary deed, for example a deed of sale and purchase agreement, deed of lease agreement and other deeds.

b. Matters ordered by laws and regulations are matters relating to formal material that must be included in the deed so that the deed meets the requirements to be called an authentic deed..

The form of responsibility carried out by a notary depends on the mistakes he has made. If

\footnotetext{
${ }^{1}$ M.U.Sembiring, Teknik Pembuatan Akta, untuk lingkungan sendiri, (Medan: UniversitasSumatera Utara, 1997), hal. 51.
} 
the notary violates criminal rules such as forgery and so on, the notary is obliged to carry out criminal liability in the form of corporal punishment or fines. If what is violated is a civil law, the notary is subject to compensation for the deed he made and the deed made, the strength of the proof falls under the hand:

1. Criminal liability :

A form to determine whether a person will be released or convicted of a crime that has occurred.

2. Civil liability :

Article 1 point 7 UUJN states that a notary deed is an authentic deed made by or before a notary according to the form and procedure stipulated in this law. This article is an affirmation of article 1868 of the Civil Code which states "An authentic deed is a deed made in a form determined by law by or before a public official authorized for that purpose at the place where the deed was made.".

Acts of falsification of authentic deed committed by a notary public as with the issue raised by the author, fulfilling the elements of unlawful acts in accordance with article 1365 of the Civil Code that states that in order for an act to be categorized as an unlawful act that is:

1. There must be an act (Daad) What is meant by the act of "Daad" in the sense of the element of breaking the law is;

a. Active Action

Where if someone commits an act that is prohibited or contrary to the law. Active action is also called Culfa in Commitendo. In this active action is equated with onwetmatig. Where a new act is considered a violation of the law (Onrectmatig) if it is against the law in force at that place (Onwetmatig).

b. Passive/negative actions

The meaning of passive action here is if someone ignores something that must be determined by law. Where he does not do something that according to the law he must do. By not doing something that he should have done according to the law, the person can be considered to have fulfilled the element of committing a passive act.

2. The act must violate the law (Onrectmatig) The element is against or violates the law in the civil category, then the basis for the element of an unlawful act according to article 1365 of the Civil Code is if a legal subject has violated, namely::

a. Violating written rules, which consist of:

1) Contrary to legal obligations (Rechtsplicht).

2) Violating the subjective rights of others..

b. There must be a loss (Schade):

The existence of an element of loss is also implied in the elements of unlawful acts.

\section{E. Legal Basis of Notary Self Protection Clause}

The inclusion of a Notary self-protection clause in this deed is ambiguous, because the contents in a deed are an agreement of the parties made before a Notary in accordance with Article 38 paragraph 3 letter (C) the Notary Office Act (UUJN) which reads as follows:

"The contents of the deed are the will and wishes of the interested parties"

Notary public shall be responsible for all aspects of the formality of the deed made by or before it. And against the content of the deed which is the will of the parties themselves, not all the will of the parties must be granted Notary Public because it must also be remembered the provisions of the :

Article 1335 of the Civil Code :

An agreement without cause, or made on the basis of a false or forbidden cause, has no power.

Article 1336 of the Civil Code :

If a cause is not stated, but there is a cause that is not prohibited, or if there is another cause that is not prohibited other than what is stated, the agreement is valid.

Article 1337 of the Civil Code :

A cause is prohibited, if the cause is prohibited by law or if the cause is contrary to morality or public order.

Article 1338 of the Civil Code :

All agreements made in accordance with the law apply as law to those who make them. The agreement cannot be withdrawn other than by agreement of both parties, or for reasons 
determined by law. Approval must be carried out in good faith.

Article 1339 of the Civil Code :

Agreement does not only bind what is expressly specified in it, but also everything which by its nature consent is required based on justice, custom, or law.

Article 1340 of the Civil Code :

Agreement is valid only between the parties that make it. Agreement cannot harm third parties; the agreement cannot provide benefits to third parties other than in the cases specified in article 1317.

The inclusion of a Notary self-protection clause in a notary deed has no legal force. It can be said that because in Article 38 of the Law on Notary Positions which outlines the systematics of each notary deed, there is no provision that regulates the notary self-protection clause. In addition, it is also emphasized in paragraph (3) letter $\mathrm{c}$ that the contents of the deed are the will and wishes of the parties concerned in the deed. Then in accordance with the provisions of Article 53 of the Law on Notary Positions, it is not allowed to regulate the notary deed which gives rights and/or benefits to the notary himself. Therefore, the inclusion of a notary self-protection clause in the notary deed is considered inappropriate and deviates from the existing rules.

\section{DISCUSSION}

\section{Factors Behind Notaries Using Self-Protection Clauses}

\section{A. Purpose of Use of the Self Protection Clause}

The purpose of the notary to use this self-protection clause is nothing but to minimize the possibility of the notary being involved in the problem, then the notary adds a clause in the deed. The additional clause is intended as a self-protection measure to protect the notary from being involved in the legal process. ${ }^{1}$ The addition of this clause essentially states that the parties hereby release the Notary from lawsuits.

Even though the Notary has exercised his authority in accordance with the Law on Notary Positions and the Notary Code of Ethics, it is not just that notaries are free from legal snares. Notaries are prone to being hit by the law, not only because of internal factors that come from within themselves such as carelessness, but also due to external factors that trap the Notary, such as community morals. Notaries are faced with the problem of circulating original but fake documents such as Identity Cards (KTP), Family Certificates, Certificates, Sale and Purchase Agreements, Decision Letters (SK) and so on. Though the document contains legal consequences for the owner. Notaries refer to these documents in carrying out their services as public officials who are appointed to represent the state to make authentic deeds.

\section{B. Benefits of Self Protection Clause}

If seen from the sound of the clauses and the purpose of the inclusion of the self-protection clause that has been discussed, of course the notary has the hope that the clauses included in the deed can provide protection for the notary in carrying out his role.

The authority of a notary in UUJN regarding the inclusion of a notary self-protection clause creates confusion regarding its inclusion because there is no authority rule that regulates the selfprotection clause and refers to the provisions of article 38 paragraph 3 letter $\mathrm{c}$ of the Notary Position Act (UUJN)..

According to Insan Kurnia Jaya said that the use of a notary self-protection clause is not prohibited to be used because there are no rules that prohibit it, as long as there are no rules prohibiting the use of this self-protection clause, it is legal to use, on condition that it must be read in front of the parties and the parties do not mind to the inclusion of this self-protection clause, then it is the desire of the parties. $^{2}$

Samsaimun said that the use of the self-protection clause listed in the notarial deed is a form of prudence of a notary in formulating the deed considering the confronters who come to the notary and convey their will to be set forth in the deed they want. But keep in mind that the notary must filter the will, whether what the parties submit has the potential as legal action or not, so that it can be the basis for a notary to draw conclusions or actions, whether it is necessary to include self-protection explicitly in the deed or not. It is a notary caution in making a deed. ${ }^{3}$

Wayan Parta argues that the application of self-protection clauses is too excessive to use, because by carrying out their duties and positions in accordance with the procedures set by the law has become a protector for notaries. If the notary wants to put self-protection against him then do not pour

\footnotetext{
${ }^{1}$ Hasil wawancara dengan Bambang Gede, S.H, Notaris di Kabupaten Lombok Barat, pada tanggal 30 April 2021.

${ }^{2}$ Hasil wawancara dengan Lalu Insan Kurnia Jaya, S.H, M.Kn. Notaris di Kota mataram, pada tanggal 22 April 2021.

${ }^{3}$ Hasil wawancara dengan Dr. Samsaimun, S,H., M.Kn. Notaris di Kabupaten Lombok Barat, pada tanggal 12Januari 2021.
} 
into the body of a deed, but poured into a separate letter such as a statement of authenticity of the file or poured after the closing of the deed. According to him the application of this self-protection clause is free to apply because he has not seen that the clause is effective to fortify himself for notary public, meaning he has not seen any court ruling that allows or the judge considers the ruling on the basis of the selfprotection clause in case of dispute in a deed. ${ }^{1}$

\section{Common Issue}

In practice, in carrying out his duties and positions notary is required to always apply the principle of prudence to the deed he made as a public official. The principle of prudence requires notaries to always be careful in carrying out their duties and positions, implementing laws and regulations, especially in the field of notary.

Although the notary performs his duties and positions properly and correctly does not guarantee the notary is not exposed to legal problems, some problems that usually occur, namely:

1. In the case of making a deed of recognition of debt. The debtors and creditors come to the Notary public and tell their wishes that the need for legal certainty for legal action that they will direct is about receivables. Therefore, the parties pour their desired provisions in the form of a deed of debt recognition. A deed of recognition of debt is a deed based on the will of the creditor and the debtor governing the debt to be paid by the debtor within a certain period of time and amount. When default debitors and creditors have difficulty collecting, creditors make complaint reports and news of inspection events to the police. To follow up the complaint, the police will then call a notary public on the basis of the need to complete the news of the examination event, to provide information because the receivables agreement between the parties is set forth in the form of a notarial deed in question.

2. The next issue is the creation of a deed of sale and purchase of shares. The shareholders in a company want to sell part / all of its shares to interested parties. Once the appropriate buyer is found, the seller and the buyer of the shares then face the notary and explain their intentions and will which are then agreed to make a deed of sale and purchase of shares. The initiative came from the parties who wanted to pour the share sale and purchase agreement in the form of a notaril deed so that it has the perfect evidentiary power. After the completion of the sale and purchase process, it was later discovered that the money used by the buyer of the shares was the result of Money Laundering Crimes. Investigators then conduct an investigation and include Notary public as witnesses or as suspects because it is considered to have helped the existence of Money Laundering Crimes. Whereas if you look in terms of the duties of notary positions, it is very unlikely that notaries know where the buyer's money comes from so it is not appropriate if the notary is considered to participate or assist.

From this issue, there is no harm in using the self-protection clause to be careful. But not all notary deed must be used self-protection clause, such as deed of selling power, deed of establishment of limited liability company, deed of establishment of CV, and so on.

\section{The reason behind the use of the self-protection clause}

The growing needs and development of cases in the realm of notary activities make authentic deed, the more potential for notaries who are in good faith and carry out their activities in accordance with procedures can be entangled in legal problems therefore the self-protection clause listed notary in the deed partij is an effort to protect notary self-involvement in legal process. The appearance of a self-protection clause is the experience of a notary public in the face of dishonesty does not explain or bring false or falsified documents.

There are several reasons behind notaries including this self-protection clause, namely;

1.Follow the draft deed from the internship.

According to one of the notaries who in this study did not wish to be named, said that usually only young notaries dominantly use the self-protection clause because: ${ }^{2}$

a. Lack of experience as a notary.

b. Lack of confidence in making the deed.

c. Feel that the self-protection clause can provide legal protection.

2.Prudential Principle

The purpose of the principle of prudence is nothing but that the notary is always in the correct signs. With the implementation of the principle of prudence is expected to keep public trust in notaries high, so that the public is willing and not hesitate to use the services of

\footnotetext{
${ }^{1}$ Hasil wawancara dengan Wayan Parta, S.H, Notaris di Kabupaten Lombok Barat, pada tanggal 14 Maret 2021.

${ }^{2}$ Hasil wawancara dengan beberapa notaris di kota mataram yang tidak ingin dicantumkan namanya dalam penulisan tesis ini
} 
notary public.

3. Increase confidence.

Because it is often found that notary public is questioned by the parties or other parties who then ensnare the notary as a party who participates in, or helps to commit a criminal act. Therefore, notary wants to further strengthen its protection and include a self-protection clause in its deed to increase notary confidence.

4. Lack of Understanding of Law Enforcement

The lack of understanding of the ranks of the government and other law enforcement about notaries can be seen from the General Legal Entity Administration System that requires notaries to agree on some things such as the correctness of the contents of documents. Notary public is required to state that the documents inputted by the notary are true and the notary shall be responsible for it. Whereas the documents used by notaries in the Administrative System of the General Legal Entity are documents brought by the parties whose truth and authenticity are not known to notaries because the notary only pours the data submitted by the confronters and is not entitled to declare a genuine or false document. Therefore, it is necessary to have a common perception between notaries and government officials as well as other law enforcers regarding the limitations of the notary's responsibility as a general official making the deed It should be understood and understood that the truth contained in the notarial deed is limited to the formal truth.

\section{Conclusion}

1. The inclusion of a notary self-protection clause in a notary deed has no legal basis. It can be said that because in Article 38 of the Law on Notary Positions which outlines the systematics of each notary deed, there is no provision that regulates the notary self-protection clause. In addition, it is also emphasized in paragraph (3) letter $\mathrm{c}$ that the contents of the deed are the will and wishes of the parties concerned in the deed. The contents of the deed describe the provisions, rights and obligations between the parties concerned. The position of the notary in the deed is not as one of the parties concerned, but as an official who expresses the will of the parties. Then in accordance with the provisions of Article 53 of the Law on Notary Positions that in a notary deed it is not allowed to regulate provisions that give rights and/or benefits to the notary himself. Therefore, the inclusion of a notary self-protection clause in the notary deed is considered inappropriate and deviates from existing rules.

2. The growing need and development of cases in the realm of notary activities to make authentic deeds, the more potential for notaries who have good intentions and carry out their activities according to procedures can be caught in legal problems, therefore the self-protection clause included in the notary partij deed is an effort to protect the notary from being involved in the legal process. The reasons behind the notary using this self-protection clause include: 1 . Following the draft deed from the internship place, 2. the principle of prudence, 3. increasing the confidence of the notary, and 4. Lack of understanding of law enforcers about the duties and responsibilities of a notary. These four reasons are the main reasons for notaries to use this protection clause. the self-protection clause in the notary deed is basically not required, but based on the reasons above, this clause is deemed necessary to exist in the deed. To get an answer about whether or not this clause is necessary, it is necessary to see whether the existence of this clause can provide protection to the notary or if the existence of this clause backfires on the notary. This clause is not mandatory, it is facultative depending on whether the notary himself wants to use it or not, because if there is an issue, it is possible to be sued.

\section{Suggestion}

1. The inclusion of a notary self-protection clause in a notary deed has no legal basis and force and is considered inappropriate and deviates from existing rules. There is a need for rules that regulate and stipulate provisions regarding the inclusion of this self-protection clause because there is still no legal rule that explains explicitly whether or not this clause can be used so that it becomes a difference of opinion among notaries.

2. If the notary still wants to increase his protection, it would be better if the self-protection clause added by the notary in the contents of the deed is made in the form of a separate attachment such as the fingerprint sheet. The statement letter which is a separate sheet is also attached to the minutes of the deed as an inseparable part. This statement letter may contain statements from the parties concerned in the deed that the confronters guarantee the truth and are responsible for the contents of the deed including identity, letters and documents that are shown or submitted to the notary and release the notary from all lawsuits, both civil, criminal law, or state administration. However, the attachment to the statement letter does not have a regulatory basis so that it does not have legal force. It is hoped that the government can further regulate the existence of the attachment in order to provide certainty for the notary's self-protection, 
especially from the legal process regarding the contents of the deed that takes into account the material truth. With the enactment of regulations regarding attachments for the self-protection of the notary, the attachment must be attached to the minutes of the notary deed and has legal force so that in carrying out his duties, the notary can refer to the regulation so that the confronters are willing to sign it..

\section{REFFERENCES}

\section{Book}

Abdul Ghofur, 2009, Lembaga Kenotariatan Indonesia, Yogyakarta: UUI Press, Yogyakarta

Abdulkadir Muhammad, 2004, Hukum dan Penelitian Hukum, PT. Citra Adiyta Bakti, Bandung.

Abdulkadir Muhammad, 2006, Etika Profesi Hukum, Citra Aditya Bakti, Bandung.

Abdulkadir Muhammad, 2010, Hukum Perusahaan Indonesia, Citra Aditya Bakti, Bandung.

H. Budi Untung, 2002, Visi Global Notaris, Yogyakarta.

Habib Adjie, 2008, Sanksi Perdata Dan Administratif Terhadap Notaris Sebagai Pejabat Publik, Refika Aditama, Bandung.

Habib Adjie, 2011, Hukum Notaris Indonesia (Tafsir Tematik Terhadap Uu No. 30 Tahun 2004 Tentang Jabatan Notaris) PT. Refika Aditama, Bandung.

M.U. Sembiring, 1997, Teknik Pembuatan Akta, untuk lingkungan sendiri, Universitas Sumatera Utara, Medan. Muhammad Syaifuddin, 2012, Hukum Kontrak, Mandar Maju, Bandung.

Munir Fuady, 2002, Hukum Bisnis Dalam Teori Dan Praktek, Citra Aditya Bakti, Bandung.

Salim HS, 2016, Teknik Pembuatan Akta Satu (Konsep Teoretis, Kewenangan Notaris, Bentuk Dan Minuta Akta) Rajawali Pers, Jakarta.

Salim HS, 2018, Peraturan Jabatan Notaris, Sinar Grafika, Jakarta.

Salim HS, dan Erlies Septiana Nurbani, 2017, Penerapan Teori Hokum Pada Penelitian Tesis Dan Disertasi, Rajawali Pers, Jakarta.

Sumaryono, 1995, Etika Profesi Hukum :Norma-Norma Bagi Penegak Hukum, Kanisius, Yogyakarta.

\section{Regulations}

Kitab Undang-Undang Hukum Perdata (Burgerlijk Wetboekvoor Indonesie)

Putusan Mahkamah Agung Republik Indonesia Nomor : 702 K/SIP/1973, tanggal 05 september 1973.

Undang-Undang Nomor 2 Tahun 2014 tentang Perubahan Atas Undang-Undang Nomor 30 Tahun 2004 tentang Jabatan Notaris.

Yurisprudensi Mahkamah Agung Republik Indonesia Nomor: 294 K/Sip/1971, tanggal 7 Juni 1971.

Pasal 65 Undang-Undang Jabatan Notaris No. 2 Tahun 2014 Perubahan Atas Undang-Undang Jabatan Notaris No 30 Tahun 2004 tentang Jabatan Notaris .

\section{Interview}

Hasil wawancara dengan Bambang Gede, S.H, Notaris di Kabupaten Lombok Barat, pada tanggal 30 April 2021.

Hasil wawancara dengan Dr. Samsaimun, S,H., M.Kn. Notaris di Kabupaten Lombok Barat, pada tanggal 12 Januari 2021.

Hasil wawancara dengan Lalu Insan Kurnia Jaya, S.H, M.Kn. Notaris di Kota mataram, pada tanggal 22 April 2021.

Hasil wawancara dengan Wayan Parta, S.H, Notaris di Kabupaten Lombok Barat, pada tanggal 14 Maret 2021. 